\title{
REFLEXIVIDADE NATIVA: QUANDO A CRENÇA DIALOGA COM A DÚVIDA NO PERÍODO DE FINADOS*
}

Mísia Lins Reesink

Em um artigo instigante sobre a escatologia krahó, Carneiro da Cunha sugere que, em sociedades tais como a krahó, a dimensão escatológica seria como um "terrain vague" em que especialistas e leigos poderiam criar e especular, tendo como consequência uma multiplicidade de versões, ao contrário do que aconteceria no campo da reprodução da sociedade krahó, em que haveria um maior controle social. Nesse contexto, a autora afirma que " [...] a escatologia não aparece como um reflexo da sociedade, como foi muitas vezes suposto, mas como uma reflexão sobre suas condições de existência" (Carneiro da Cunha 1986:79).

Aproveitando o insight de Carneiro da Cunha, penso que, mesmo em sociedades em que há o estabelecimento de uma ortodoxia escatológica, esta permanece como referência, mas não consegue se impor como verdadeiramente dominante: ${ }^{1}$ ou seja, mesmo nesses casos, o campo escatológico permanece, em certa medida, um "terrain vague", eminentemente especulativo, conflituoso, criativo e reflexivo, aberto tanto a especialistas como a leigos e, consequentemente, capaz de fornecer uma multiplicidade de versões.

Isso é passível de ser percebido entre católicos residentes do bairro de Casa Amarela, em Recife. Apesar de partirem de uma espacialidade cuja referência primeira são os lugares ortodoxos do catolicismo (céu, inferno, purgatório e limbo), ${ }^{2}$ esses católicos reconfiguram constantemente esses espaços, multiplicando-os (como o céu); incluindo novos (como a Terra); excluindo outros (como o purgatório e, mesmo, o inferno) ou todos (pensando o "outro mundo" como impossibilidade); ressignificando-os, realizando amálgamas ou incluindo espaços estrangeiros à lógica católica (M. Reesink 2003). ${ }^{3}$ Este pequeno esboço possibilita, assim, entrever uma diversidade na concepção da espacialidade escatológica católica ou, como diria Carneiro da Cunha, dessa cosmografia, mesmo que, como dito, sob muitos aspectos resguarde a referência à ortodoxia católica — demonstrando, assim, como este campo 
se revela como dimensão privilegiada para pensar sobre o alcance e, porque não, o mecanismo da démarche reflexiva dos católicos.

Essa cosmografia católica, rapidamente esboçada aqui, é assim um dos componentes fundamentais das representações católicas referentes ao fenômeno da morte. Entretanto, não se pode esquecer, como já dizia Hertz (1905-1906), que a análise deste fenômeno deve levar sempre em conta as crenças, os ritos sociais e as emoções, pois lhe são constitutivos. Neste artigo, tendo em vista o seu escopo, pretendo privilegiar a dimensão das representações e do ritual como loci por excelência do processo de reflexividade católico, sem com isto pretender diminuir o lugar das emoções nesse processo. Para isto, fiz um recorte do Período de Finados e, particularmente, do ritual de acender velas. As análises aqui elaboradas só foram possíveis a partir dos dados obtidos através de pesquisa etnográfica realizada entre moradores católicos do (e no) bairro de Casa Amarela, em dois períodos: 1994-1995 e 1998-1999, ${ }^{4}$ com observações do ritual de Finados no cemitério de Casa Amarela em 1994, 1998, 2007, 2008 e 2009. Além disso, de forma secundária e com intenção heurística, serão acrescentados os dados obtidos a partir de um questionário aplicado em 1998 nos cemitérios de Casa Amarela e de Santo Amaro (o maior do Recife), destino fúnebre dos católicos de Casa Amarela. ${ }^{5}$ Portanto, retomo estes dados sobre Finados para repensá-los à luz da dinâmica da dúvida-ceticismo-crença como dimensão reflexiva intrínseca ao processo religioso.

\section{Reflexividade religiosa: ritual, crença, dúvida e ceticismo}

Quando se pensa em termos de reflexividade religiosa é, sobretudo, a sua implicação na formulação da dúvida e do ceticismo que interessa a maior parte dos pesquisadores, sendo este também o meu caso. Entretanto, seria interessante também destacar que a reflexividade religiosa tem outras implicações, além da dúvida e do ceticismo. Nesse sentido, Hojbjerg (2002) apresenta três tipos de reflexividade analisadas pelos autores do dossiê especial da revista Social Anthropology sobre "reflexividade religiosa": a forma organizacional da ação ritual, incluindo linguagem ritual e modos de transmissão de ideias religiosas; a experiência de eventos e a presença de alternativas "visões de mundo"; a objetivação das representações religiosas a partir do conflito acerca da doutrina e/ou da ação adotada por não participantes em relação à religião em questão (Hojbjerg 2002). ${ }^{6}$

Pode-se afirmar, assim, que a análise antropológica do ceticismo e da dúvida, relacionados à crença, há bastante tempo tem interessado os pes- 
quisadores, apesar disto se dar de uma maneira não orgânica. Talvez um dos trabalhos mais conhecidos sobre a questão seja o livro de Evans-Pritchard (1978) sobre os Azande, apesar de majoritariamente se sublinhar a discussão do antropólogo sobre a racionalidade da crença azande na bruxaria. Entretanto, é, sobretudo, o processo (que inclui modos) de reflexividade, desenvolvido pelos nativos, que avalia e analisa a presença de fato ou não da bruxaria, dentro, é claro, de um contexto cosmológico que informa a sua presença como possibilidade - e mesmo possibilidade cotidiana, que está em jogo na discussão do autor. O que nos interessa aqui, realmente, é que, segundo a análise de Evans-Pritchard, se a bruxaria é considerada um fato, a sua ocorrência (a quem, quando, onde, como etc.) está sempre sujeita à reflexão e, não secundariamente, ao ceticismo e à dúvida.

Uma discussão semelhante, embora dentro de outro registro, é feita por Lévi-Strauss no seu artigo sobre o feiticeiro e sua magia (1975). Nesse pequeno trabalho, ele discute a questão da produção do ceticismo entre povos indígenas americanos. Assim, de modo análogo ao caso azande, os Nambikwara são céticos ou põem em dúvida a natureza real de um fenômeno envolvendo o seu xamã: apesar de não se questionar a possibilidade do fenômeno "mágico" existir, reflete-se se isso teria ocorrido de fato no caso em questão. A discussão mais interessante apresentada por Lévi-Strauss, todavia, é a do relato do índio kwakiutl: extremamente cético sobre a eficácia dos xamãs, ele se inicia nessa atividade visando desmascará-los como farsantes; à medida que vai confirmando a sua certeza na farsa, vai se transformando ele mesmo em um poderoso xamã. Nesta situação etnográfica, é possível perceber toda a tensão e, ao mesmo tempo, a dinâmica entre dúvida, ceticismo e crença. Como finaliza Lévi-Strauss:

A atitude do começo se modificou, pois, sensivelmente: o negativismo radical do livre-pensador cedeu lugar a sentimentos mais matizados. Existem verdadeiros xamãs. E ele próprio? Ao fim da narrativa, não se sabe; mas é claro que exerce ofício com consciência, que é orgulhoso de seus sucessos e que defende calorosamente, contra todas as escolas rivais, a técnica da plumagem ensanguentada, da qual parece ter perdido de vista, completamente, a natureza falaciosa, e da qual zombara tanto no início (Lévi-Strauss 1975:206).

Além desses dois trabalhos, outro merece ser citado no que se refere à análise etnográfica de crença e dúvida, o processo reflexivo intrínseco à religião. Trata-se da obra de Favret-Saada (1977) sobre a feitiçaria no Bocage francês. Em seu livro, a autora demonstra o jogo, ou a "guerre des mots", e a dinâmica entre crença, dúvida e ceticismo, que passa sempre pelo poder 
e pela eficácia reconhecida, tanto do feiticeiro como daquele que quebra o feitiço. Além disso, aborda igualmente no texto a questão das estratégias desenvolvidas nessa "guerra das palavras", em que não há neutralidade possível: pode-se aqui pensar nas estratégias como uma construção prática (ou pragmática) da reflexividade religiosa.

Se estes trabalhos citados, assim como outros, lidam com o papel da dúvida e do ceticismo na reflexividade religiosa, na construção da crença, creio que a análise de Pouillon $(1982)^{7}$ foi a primeira a de fato discutir toda a implicação "ontológica", se assim posso dizer, da dúvida na crença e viceversa. Analisando o verbo "croire" (crer), o autor aponta tratar-se de um verbo paradoxal, tendo em vista que expressa tanto a dúvida quanto a segurança, acrescentando que, particularmente no que se refere à religião, " [...] acima de tudo, há sempre dúvida no coração da convicção, e que a afirmação em si mesma indica que esta sempre pode ser suspendida" (Pouillon 1982:06).

Esta abordagem "relacional" entre crença, ceticismo e dúvida como intrínseca ao processo da reflexividade religiosa e, por extensão, como intrínseca aos sistemas religiosos é também adotada pela maioria dos antropólogos que analisam a reflexividade na produção e na reprodução dos sistemas religiosos. Desta forma, Whitehouse afirma que, em determinados contextos, "[...] podemos legitimamente dizer que a dúvida e a descrença são intrínsecas à construção da experiência religiosa como fé ou convicção" (Whitehouse 2002:102). E, de uma maneira mais ampla, Hojbjerg considera que a reflexividade religiosa:

[...] incluindo ambivalência e contradições, aparece como um elemento essencial no processo de aquisição de ideias religiosas e aquelas instâncias específicas tais como a dúvida, ceticismo e o uso de técnicas ilusórias não são nem excepcionais nem necessariamente exóticas, mas ao contrário servem para sustentar a existência das ideias e práticas religiosas em geral (Hojbjerg 2002:04).

A posição aqui adotada converge com esta compreensão da reflexividade como intrínseca à produção e reprodução dos sistemas religiosos e, nesta esfera, a dúvida, o ceticismo e a crença como inerentes uns aos outros, ao menos no que se refere ao contexto religioso aqui discutido. ${ }^{8}$ A importância da dúvida e do ceticismo na produção religiosa, expressa, sobretudo, na necessidade da prova ${ }^{9}{ }^{9}$ tem sido analisada por mim em situações de peregrinações e de produção de milagres (Reesink 2000, 2005 e 2008). Entretanto, no presente texto, pretendo aprofundar a discussão em torno do ritual de Finados, em que, apesar de não haver uma mudança radical de registro, a questão da crença, ceticismo e dúvida tem outros referentes. Além 
disso, quero pensar a reflexividade não apenas como abstração, ou seja, na dimensão das representações, mas também (e especialmente) como práxis. Isto quer dizer que pretendo adotar a perspectiva de Severi que, ao analisar o ritual xamânico kuna, afirma que "A ação ritual constroi um tipo particular de ficção, um contexto especial de comunicação, em que qualquer resposta positiva implicará dúvida e incerteza, e vice-versa" (Severi 2002:38).

O autor avança ainda na ideia de que a atitude reflexiva em relação ao ritual não se dá apenas a posteriori, configurando uma parte constitutiva do próprio ritual. Nesse sentido, além da dinâmica entre crença/dúvida, o que está em jogo em Finados é a dinâmica entre ritual e representações, que no seu conjunto "fazem" Finados.

Primeiramente, apresentarei o contexto etnográfico de Finados, em que a análise acentuará aquilo que se apresenta como "afirmação e certeza" no "dia da Saudade", ou seja: aquilo que os católicos constroem reflexivamente como certeza e positividade. Em seguida, procurarei discutir mais de perto a dinâmica da dúvida-ceticismo-crença nesse contexto. Saliento que, ao afirmar descrever e discutir Finados, não levarei em conta todas as suas dimensões, concentrando a análise, em especial, no ritual de acender velas.

\section{Para compreender o "dia da Saudade"}

Conhecido como o "dia da Saudade", Finados faz parte daquilo que classifiquei como "complexo ritual funerário católico" (Reesink 2003 e 2006). Seguindo o esquema proposto por Thomas (1985), baseado em grande medida nos ritos de passagem de Van Gennep (1969 [1909]), este complexo seria composto por ritos de oblação - cuidados com o moribundo e com o corpo-cadáver; seguidos dos ritos de passagem - velório, enterramento e luto. ${ }^{10}$ Este último compreenderia diversos rituais e seu objetivo seria o de agregar a alma do morto no outro mundo e o de reagregar os sobreviventes no mundo dos vivos. Os rituais mais marcantes desse período são as missas, as idas ao cemitério no intuito de visitar os túmulos e a festa dos mortos: o dia de Finados. Entretanto, como se trata de um ritual anual e perene, pode-se avançar que esta festa revela o caráter sempre inacabado do luto (Reesink 2006).

O dia de Finados, que ocorre em 2 de novembro, teve início no século $\mathrm{XI}$, sendo o dia designado pela Igreja Católica como data em que a Igreja Militante (os vivos católicos) se lembra e se apieda da Igreja Penitente (as almas ainda não completamente salvas), sendo, portanto, uma data comemorativa muito antiga no calendário católico. Esta festa foi instaurada pelo Abade Odilon, de Cluny, França, por volta de 1030 (Schmitt 1994), ${ }^{11}$ 
expandindo-se, em pouco tempo, por todo o mundo católico como celebração de seus mortos. ${ }^{12}$

O dia da Saudade é, obviamente, festejado aqui no Brasil, atraindo milhares de pessoas aos cemitérios do país nesta época. Finados não pode ser analisado, contudo, sem se levar em consideração o dia anterior, ou seja, $1^{\circ}$ de novembro, dia de Todos os Santos. Entretanto, Todos os Santos permanece no Brasil um dia auxiliar ao de Finados ${ }_{1}^{13}$ diferentemente da França, em que o dia $1^{\circ}$ é a data preferencial de celebração dos mortos (Déchaux 1997). ${ }^{14}$ Assim, em Recife, vai-se aos cemitérios no dia de Todos os Santos especialmente para deixar tudo preparado para o dia seguinte: limpar e pintar os túmulos, colocar flores, decorá-los. Em Finados, vai-se, sobretudo, para rezar e para acender velas, para homenagear os "entes queridos". ${ }^{15}$ É claro que as pessoas podem fazer tudo no dia $1^{\circ}$ de novembro, ou tudo no dia 2 , indo ao cemitério apenas uma vez. Entretanto, creio que se pode dizer que Todos os Santos se traduz principalmente pela "limpeza", enquanto Finados implica sobretudo as rezas e as velas. Nesse sentido, a estrutura básica do período de Finados que, como dito, pode se desenvolver em dois dias ou em um, compreende: limpeza dos túmulos (que pode incluir também trabalhos de pedreiros e pintura), decoração (flores, fotos, cartazes, imagens de santos etc.), acender velas e recolhimento (rezas, pensamentos etc). Além disso, como lembra Déchaux para o caso francês, " [...] deve-se acrescentar a entrada e a saída do cemitério" (1997:81). ${ }^{16}$ Se é assim que se apresenta a estrutura mínima do ritual de Finados, esta é vivida com a presença de dezenas de pessoas que passeiam entre os túmulos: mulheres (a maioria), homens, crianças, adolescentes, carregando flores e velas, terços e lágrimas. Acompanhadas, em sua maioria, ou mesmo sozinhas, estas pessoas podem passar o dia inteiro no cemitério, aproveitando também para participar da missa campal, ou mesmo apenas o tempo necessário para arrumar o túmulo, colocar flores, acender velas e rezar.

O ritual de acender velas é, de fato, simples em sua realização. Só após o túmulo completamente limpo e arrumado, sendo as flores o adorno mais utilizado, é que as velas são colocadas sobre os mesmos para serem acesas, ato cuja duração depende da quantidade de velas e, sobretudo, se está ou não ventando: alguns túmulos, para evitar o transtorno causado pelos ventos, preveem nichos com para-ventos especialmente construídos para poder acendê-las tranquilamente. Só depois de todas as velas acesas é que se reza, seguindo-se, na maior parte das vezes, o sinal da cruz. Acender velas pode ser feito acompanhado ou sozinho, ou de forma combinada. Assim, no Finados de 2009, um senhor aparentando setenta anos solitariamente ornamentou com flores o túmulo de um de seus familiares, logo 
após enfiando na terra que cobria o túmulo diversas velas. Demorou alguns minutos para deixar todas acesas ao mesmo tempo, pois soprava uma brisa suficientemente forte para apagar algumas delas; depois de finalmente conseguir acendê-las, ergueu-se, fez o sinal da cruz, posicionando as mãos cruzadas atrás das costas enquanto rezava e encerrou o ritual também com o sinal da cruz. Algum tempo depois, umas parentas juntaram-se a ele: não contentes com a ornamentação que esse senhor havia feito e com o aspecto um tanto murcho das flores, reiniciaram todo o processo de ornamentação dos túmulos, para em seguida realizarem o ritual da vela, em que foram acompanhadas por ele.

Um dado importante, ainda, deve ser levado em consideração: mais do que estabelecer uma relação direta entre Finados e cemitério, é preciso ter em mente que este período representa principalmente $o$ momento dos defuntos católicos e, dessa forma, ultrapassa o lócus cemitério. Isto porque, em Casa Amarela - algo que, a meu ver, não se restringe apenas a este bairro de Recife - os católicos rezam, acendem velas e homenageiam os seus mortos mesmo quando eles não se deslocam para os cemitérios: a realização do ritual de Finados pode ser feita em outros ambientes como, por exemplo, nos ossuários instalados em igrejas. Mas é, sobretudo, em casa que os católicos realizam o ritual quando não vão ao cemitério: nesse contexto, o espaço privilegiado para realizar o ritual é o quintal da casa. ${ }^{17}$ Isto acontece em especial quando os restos dos parentes não se encontram mais no cemitério, mais precisamente quando não há mais túmulo, tendo em vista o sistema de rotatividade das covas $;^{18}$ mas a razão pode ser também prática: assim, apesar de ter ido em Finados ao cemitério de Casa Amarela, Edite preferiu acender velas e rezar em casa, pois o vento estava muito forte e a impedia de acender as velas. De qualquer forma, para a maior parte dos católicos, a realização do ritual de Finados é subsequente à morte de um parente ou de uma pessoa amada.

\section{Por quem e por que se "faz" Finados?}

A questão pode parecer surpreendente, mas, na realidade, se impõe para nos fazer olhar as relações que se estabelecem entre Finados, as concepções do "outro mundo" e os laços entre mortos e vivos, relações estas que analisei longamente em outros momentos (Lins [Reesink] 1995; Reesink 2003 e 2006). Isto porque este período está, antes de tudo, ancorado nas relações entre vivos e mortos, elas mesmas relativas à maneira como os católicos representam o outro mundo. Nesse sentido, o objetivo final do ritual 
de Finados é a salvação das almas dos mortos. Entretanto, não se trata de "qualquer morto": é primeiramente para os parentes mortos e, em seguida, para as almas do purgatório que se realiza Finados. ${ }^{19} \mathrm{O}$ "quem" da questão se traduz, sobretudo, por "meus entes queridos".

Finados é como uma festa. Porque, você pode notar, quando a gente chega lá, tem uma multidão. A quantidade de gente é grande, porque todo mundo quer ir lá, porque chegou o tempo de ficar do lado dos parentes. [O parente] sabe..., eu acho que nessa época ele sabe que a gente está lá (S. Ênio).

Eu acendo velas pelos meus [entes queridos], pelas outras [almas]. Pois é uma devoção para fazer todos os anos. Aquele que tem esta devoção faz todos os anos, ele tem também essa alegria ( $\mathrm{S}$. Lemos).

- Você acha que o dia de Finados é importante?

- Sim!

- Por quê?

- Porque eu acho que, neste dia, as almas, os espíritos, eles estão lá... Eu acho que é mesmo um dia dado por Deus para que eles possam, sabe? Para eles reverem a família, sei lá! Eu não sei te explicar. Eu fui criada nessa crença, aí a gente a segue... Mas, eu não sei te dizer se eles voltam [ao cemitério] ou se do lugar deles mesmos eles veem o que a gente faz (Carla).

Essas palavras deixam claro que Finados é especialmente uma festa "em família". Segundo Déchaux, "o dia dos mortos, através da sua ritualização, aparece essencialmente como uma celebração familiar" (1997:93), levantando a hipótese de que "a família parece ser ao mesmo tempo o objeto e o sujeito" (1997:93). De fato, como diz o S. Ênio, os cemitérios estão em festa porque as pessoas sabem que é a época propícia para reunir a família, para se estar próximo dos parentes, pois tudo indica que, neste dia, os mortos recebem a "permissão" divina de reencontrar os seus parentes da Terra, como disse Carla.

No que se refere ao "por que" da questão feita, a razão primeira é a salvação completa dos seus entes queridos. Aqui, é importante lembrar que, na cosmologia católica, os indivíduos que morreram com alguma dívida terão de se purificar em algum lugar intermediário entre o céu e o inferno: os vivos podem ajudar a completar a salvação dos mortos através das rezas e das velas. ${ }^{20}$ Além disso, outras razões aparecem: devoção às almas do purgatório e o dever de ajudá-las em sua salvação; a tradição e o compromisso com a religião católica; as promessas e os compromissos estabelecidos entre parentes mortos e vivos. Entretanto, é na continuidade da reciprocidade 
afetiva que os vivos justificam esta obrigação. Vejamos o seguinte diálogo com S. Breno e sua mulher, D. Lola.

- O senhor vai ao cemitério em Finados?

- Claro, enquanto eu estiver vivo, eu tenho esta penitência, né? Para com os meus entes queridos. Pais, sogros, irmãos! É uma coisa minha. Então, não custa nada ir lá venerá-los, não é? Não há nenhum peso, nenhuma retribuição! Eu vou, acendo algumas velas, fico lá o dia todo, ou uma parte do dia. Volto satisfeito.

- O senhor reza?

- Claro.

- Em intenção de quem?

- Não, eu rezo em intenção dos mortos. A primeira reza é para que eles tenham boas horas, bons lugares nesses dias, não é? Mas, isto não é apenas para este dia, é desde que eles terminaram o tempo deles aqui na Terra... [S. Breno].

- Que fique claro: não é a Igreja que manda. A gente faz isto como uma homenagem aos entes queridos [D. Lola].

- É um ato de amor [S. Breno].

- A gente sabe que os restos estão lá, os ossos, então a gente tem este hábito, isto vem de nossos avós, este costume de ir ao cemitério em Finados, acender velas e colocar flores [D. Lola].

Realizar o ritual de Finados estaria, assim, mais relacionado às relações afetivas do que a uma ordenança da Igreja, como quis sublinhar D. Lola. Para Seu Breno, contudo, trata-se de fato do amor que se sente em relação aos mortos e da salvação das suas almas no outro mundo. De qualquer forma, mais do que o "dogma" da Igreja, o que se quer acentuar é a legitimidade desta ação, justificada pelo costume e pela tradição. ${ }^{21}$

\section{Finados: velas, rezas, salvação e reciprocidade}

O dia de Finados é sobretudo uma data na qual os católicos rezam por seus mortos. Entretanto, a prece não está sozinha nesse contexto: a seu lado, encontra-se muitas vezes a vela. Assim, quando se fala da vela, evoca-se obrigatoriamente a reza. Além disso, acender uma vela implica em rezar, pois a chama é associada à reza. Nesse sentido, pode-se dizer que a vela e a reza compõem um par nesse sistema.

- Eu creio que a reza, a vela, eu acho que é como um bálsamo espiritual. Eu acho que eles recebem como... Como uma luz. Sei lá! Porque a reza é uma coisa 
muito poderosa, não é? Eu acho que não existe nada melhor que uma reza por uma pessoa que já morreu (Raquel).

- Por que a gente acende velas? Pelas almas de sua família. Pelos nossos parentes já mortos..., e também dos outros. Porque a gente já tem este costume da avó, do avô, tudo isto, para fazer esta penitência. Então a gente faz também. Meus pais são mortos... Eu já acendi aqui [na sua casa] a vela pelo meu pai, pela alma do meu pai, da minha avó, do meu avô, dos meus padrinhos, das minhas madrinhas. A gente se senta, cada um reza os benditos, estas rezas para as almas. As pessoas ignoram, mas como a gente nasceu nisto, a gente faz isso sempre... A gente reza um Pai Nosso, uma Ave Maria, Santa Maria, Salve Rainha, o Credo. No fim, a gente oferece em intenção das almas que são mortas (D. Janice).

Se, como dito, vela implica reza, em contrapartida, quando um católico diz rezar pelos mortos, isto não implica necessariamente acender velas, como é possível ver nos cemitérios em dia de Finados. ${ }^{22}$ Dessa forma, há aqueles que subentendem sempre a reza quando afirmam a importância da vela, enquanto outros, ao reforçarem a importância da reza, anulam a eficácia da vela.

Contudo, mesmo que alguns católicos minimisem sua eficácia e sua necessidade, a vela, assim como a reza, é um dos componentes principais no estabelecimento das relações entre mortos e vivos (Lins [Reesink] 1995).

- Por que é importante acender velas?

- Olha, eu acho assim, acho que é uma maneira da gente, da pessoa, do espírito, a alma sei lá! Ver que a gente está se lembrando dele, né? E está assim... Porque às vezes a gente faz coisa errada e acho que não se arrepende e depois vai para outra vida e a gente aqui, quem fica, acho que vai pedindo, pedindo a Nossa Senhora para interceder por aquela alma, né? Aí acho que ali Deus vai vendo se aquela pessoa merece ou não, aí vai sendo uma luz para eles (Edite).

- Eu não digo que não ajuda, tem muitos que dizem assim: "não, acende vela, vai clarear a alma dele aonde ele tá; ele tá num lugar muito escuro, então a gente vai acendendo vela..." Não acredito, porque tem gente que acende vela só na época de Finados. Então, aquela vela não vai durar todo tempo, entendeu? Então eu acho que não existe. Que a luz quem dá é Deus, essa vela que a gente acende é só pra lembrar mesmo aquela pessoa que morreu, em homenagem àquela pessoa que a gente gostou muito e sente por ela, aí a gente acende vela. Mas, que adianta alguma coisa, não adianta, não (Ana). 
Como a reza, a vela é um sinal que os vivos enviam aos entes queridos para reafirmar o seu amor e a sua memória. Ela ajuda, assim, a tornar vivos e mortos felizes. Além de sua função salvífica, este objeto é ainda demonstração da continuidade da afetividade. É bem verdade que, como Ana, alguns católicos retiram o conteúdo propriamente sagrado da vela. Mas o que importa aqui é que a vela compõe com a reza um conjunto de elementos que os vivos têm para se comunicar com os mortos. De qualquer forma, para a maioria dos católicos de Casa Amarela, a vela conserva conjuntamente o seu caráter sagrado e afetivo.

- Em Finados, a gente acende velas, a gente reza e se lembra.

- E isto é importante?

- É importante. A gente sempre lembra. A gente acende uma vela para um defunto no tempo de Finados; é porque eles... Sempre a gente tem que se lembrar deles e é muito bom ter uma luz. É muito bom, não é? Porque têm muitos... É que nem a gente: cada um tem o seu lugar de ficar. Então, tem muitos que precisam d'uma luz. Então, é bom a gente acender e rezar, para que Deus escute as nossas orações, não é? Que só quem pode fazer isso é a gente quando está vivo (Alice).

Este discurso de Alice contém todos os elementos que fazem da vela um fator crucial nas relações entre vivos e mortos: lembrança, amor, salvação. Além disso, mais uma vez demonstra que existe um dia em que estas relações são particularmente possíveis e encorajadas: o dia de Finados.

Talvez fosse o momento de notar um dado obtido dos questionários aplicados em Finados, em 1998: assim, em relação ao ritual de acender velas, ${ }^{23} 84,5 \%$ dos que se autoidentificaram como católicos responderam que realizaram essa ação ritual. Este dado do questionário aponta para o que minha experiência de campo tem confirmado - tanto através dos meus informantes quanto por meio de minhas observações no cemitério em Finados o lugar incontestável que a vela ocupa nas relações entre os vivos e os mortos nesse contexto. Ainda mais quando parece ser um elemento pouco usado em outros países católicos, pelo menos no caso dos países europeus, até onde sei. ${ }^{24}$ Entretanto, no Brasil, a vela adquire outra evidência, porque possui uma função e uma eficácia, o que a torna muito mais do que um objeto.

- E por que as velas?

- Minha filha, a luz representa a vida, não é? A vida é Jesus Cristo [risos]. Se a vida é Jesus Cristo, a luz representa a vida, a claridade. É este o sentido da 
vela, aquele que a gente usa na igreja... É como se a gente acendesse... É isto (D. Zilda).

- A vela representa o fogo do Espírito Santo. Então, por meio disto, é um símbolo bem católico, nosso, não é? Na Igreja, ela está sempre acesa (André).

Compreende-se então que o sentido primeiro da vela é a vida. Sendo símbolo de Cristo, ela carrega consigo aquele da vida. Além disso, ela é também o fogo do Espírito Santo, ou seja: a chama que acende o coração do cristão e que sinaliza, dessa forma, o começo da absolvição, pois o Espírito Santo é o sinal da transformação do pagão em um cristão, isto é, em pessoa potencialmente salva. A vela está, então, sempre presente, transformando o espaço físico/corporal em um lugar católico, tendo em vista tratar-se de um elemento de identificação católico.

A partir disto, é possível compreender o sentido da vela no regime de salvação (E. Reesink 1999): acender uma vela seria "acender" a vida. Disto decorre que este objeto/símbolo é sempre concebido e manipulado em relação à escuridão e à claridade, e isto sempre que estão em questão as almas do outro mundo.

- Talvez a vela seja uma luz para iluminar qualquer coisa que as almas precisam (Carla).

- Por que a senhora reza? Por que se reza pelos mortos?

- Ah! Porque aí as almas gostam que a gente reze para elas, né? Aí a gente dá conforto, damos conforto a elas. Estamos lembrandos deles. Acender a vela, pra mim, é acender uma luz para eles. Um pastor uma vez discutiu comigo, ele disse que a pessoa que morre não quer mais luz, não quer mais nada, porque aí já partiu para outra eternidade, não está precisando de luz, não. Eu digo: "precisa sim, eu acho que cada vela que a gente acende é uma alegria para eles, que a gente está dando uma luz para eles". Quer ver? Ninguém sabe onde ele está, se está no escuro, ou se ele está, se Deus botou ele num determinado, se ele fez um bem aqui na Terra, se ele está num lugar bom, se ele está no escuro. Porque aí eu acho que um bocado de vela que a gente acende, é uma alegria para os espíritos, é uma luz que a gente está iluminando o caminho dele. O pastor diz que não. É porque cada um tem sua opinião, seu pensamento, tem o seu jeito de pensar (D. Celita).

Nesse sentido, na lógica das representações católicas do outro mundo, aqueles que não são ainda completamente salvos estão na escuridão. Isto 
implica dizer que a salvação é luz, por isso a vela é sinônimo de vida, de acordo com D. Zilda. Ora, a salvação eterna não é estar na presença de Deus, segundo o catecismo (o que converge explicitamente com o que dizem meus informantes)? Mais próximo dele, mais luz, pois ele é a vida-luz; mais distante de Deus, menos claridade e mais trevas. Por isso o inferno é sempre representado por meus informantes como um lugar de sombras, pois está vazio da presença-luz divina; entre a plenitude de luz e o vazio de luz encontram-se, nesse contexto, todos os lugares intermediários. A consequência lógica disto é que acender uma vela equivale a enviar um pouco de "vida", do fogo do Espírito Santo, de Deus. Assim, no outro mundo, há o sofrimentoobscuridade (M. Reesink 2003), ou seja: o distanciamento do "esplendor" divino. Acendendo velas, dá-se alívio e conforto aos mortos.

É preciso, neste momento, aprofundar um pouco mais a análise das percepções que os católicos da Casa Amarela têm da vela. Não há dúvida que a relação primeira que com ela estabelecem é a de símbolo: de luz divina, de Jesus Cristo, da chama do Espírito Santo, de vida, de catolicidade. Mas há ainda uma segunda relação, que é a de contiguidade. Dessa forma, haveria uma concepção metafórica e outra metonímica (Figueirôa 1995) ${ }^{25} \mathrm{Na}$ relação metafórica, a vela é um símbolo em dois sentidos: primeiramente, digamos, como representação simples; ou seja, seria um emblema de catolicidade, de vida. Esta concepção encontra-se mais facilmente entre os católicos que não acendem velas, ou se o fazem é mais como uma marca de catolicidade. Em segundo lugar, seria um símbolo enquanto analogia, ou seja, ela conteria em si mesma uma eficácia simbólica no sentido de Lévi-Strauss; este sentido é percebido com facilidade na maior parte dos discursos dos católicos de Casa Amarela que acendem vela: esta simbolizaria a vida; ao acender este símbolo, possuidor de uma eficácia própria, estaria-se realizando uma "cura" (LéviStrauss 1975). Parodiando Lévi-Strauss, poderia-se dizer que se a chama e a luz da vela não correspondem de fato a uma realidade objetiva no outro mundo, isto não tem importância: o essencial é que os católicos creem que, simbolicamente, a chama alivia os sofrimentos das almas no outro mundo.

Passemos agora à relação metonímica com a vela, relação esta que não é muito recorrente, e nem sempre fácil de apreender, o que pode sinalizar para uma menor elaboração deste tipo de concepção entre os católicos.

- Por que a vela é importante?

- Porque... É assim: é aquela coisa, assim: como a cera se derrete ao calor do fogo, tudo de mal, tudo de ruim, que aquela pessoa teve na vida, em vida, certo? Que esteja pagando no purgatório seja queimado também, certo? É isso... É uma das utilidades da vela também. A vela também serve para isso, para queimar 
tudo assim, como eu disse a você: assim como a cera derrete ao calor do fogo, tudo quanto for de mal seja queimado também (Júlio).

- A senhora acha que a vela ajuda...?

- É. Acredito que ajuda. Não que seja a vela: a gente acende outra vela [lá], com o que a gente pede através da reza, junto com a vela (D. Cícera).

Percebe-se aí, então, relações de contiguidade: a cera da vela na Terra é a "cera" dos pecados no outro mundo. O fogo da vela que derrete a cera no mundo terreno é o "fogo do purgatório" no outro mundo. Acender uma vela na Terra implica acender uma no outro mundo para iluminar os mortos. É neste sentido que se pode afirmar que a vela tem um papel metonímico na economia de ajuda aos mortos. Contudo, mesmo nesses casos descritos, o que se encontra de fato são relações ao mesmo tempo metafóricas e metonímicas com a vela, pois esta parece ser, para estes informantes, ao mesmo tempo símbolo e contiguidade.

Todas estas discussões que foram feitas aqui nos ajudam a ter uma ideia da complexidade das relações entre vivos e mortos na cosmologia católica, ao tomar o período de Finados como chave para compreender estas relações, que envolvem tanto representações e ritos, como afetividades. Pode-se ainda vislumbrar como este período é possibilidade de reflexividade sobre e para a cosmologia católica.

\section{Finados como reflexividade: dúvida, ceticismo, crença, tradição, commitment}

Seja através de minhas observações nos cemitérios, seja por meio das conversas e diálogos com meus informantes, o que fica evidente é que "fazer" Finados, particularmente rezar e acender velas, é um ato que implica reflexividade e engajamento, o que por sua vez, dentro da perspectiva aqui adotada, implica a dinâmica entre crença, ceticismo e dúvida. Neste sentido, o que sempre me intrigou em campo e nas análises dos dados foi exatamente esta dialética na constituição da reflexividade religiosa, na constituição da fé, como categoria maior.

Como discuti em outra oportunidade (Reesink 2008), concebo a categoria fé como constituída de três sentidos e/ou operacionalidades: o primeiro, e o mais simples de analisar, é o sentido de fé como sinônimo de religião: dessa forma, há informantes que costumam falar da "minha fé, que é a católica" ou "aqueles que têm a fé católica", ou ainda "quem pertence à fé católica". 
O segundo sentido, e o que é relevante aqui para a discussão, é o de crença e suas relações com a prova, a dúvida, a confiança, o ceticismo. O terceiro sentido é o de fé como condição humana, que não discutirei aqui.

Fé como crença, especialmente no sentido de se crer na existência da sobrenatureza e da sua intervenção na natureza, parece ser o sentido mais facilmente "falado", apesar de muitas vezes ser o menos pensado. De uma maneira geral, este sentido de fé fica circunscrito à sua qualidade de "crença". Porém, parece-me que a categoria fé-crença inclui, obrigatoriamente, qualidades que nem sempre estão implicadas, em termos nativos, na crença. Uma delas é a relação de confiança e afetividade (Reesink 2003), a outra, como já estamos discutindo aqui, é a da dúvida e ceticismo. Esta discussão pode ser enriquecida se for articulada ao exame do termo crença realizado por Toren (2006), em sua análise sobre o caso do "mana" em Fiji. Assim, a autora faz uma distinção interessante entre "crer" e "saber", argumentando que "[...] podemos acabar caracterizando como crença aquilo que nossos informantes sabem" (Toren 2006:449). Entretanto, mesmo que de fato haja uma diferença de grau de certeza entre crer (relativo) e saber (absoluto), parece-me que a categoria fé no sistema cosmológico católico contém tanto a certeza relativa (que pode ser traduzida pela crença), como a certeza absoluta (o saber). Assim, os católicos sabem que Deus existe e creem na possibilidade do milagre, mas não sabem se aquele milagre específico aconteceu. ${ }^{26}$ Neste sentido, pode-se afirmar que é característico da categoria fé se constituir na própria articulação entre dúvida-ceticismo-crer-saber.

Esta dinâmica reflexiva, e intrigante, pode ser facilmente encontrada no contexto de Finados, em que um dado sugestivo resultou da pergunta do questionário sobre vida após a morte. ${ }^{27}$ Assim, entre os católicos pesquisados, $54 \%$ responderam que sim, contra $24 \%$ que responderam não acreditar, enquanto $22 \%$ tinham dúvidas. Isto fica mais interessante quando comparamos estes dados com a realização do ritual de acender velas. Assim, dos que são positivos na crença de vida após a morte, $87 \%$ acendiam velas; dos que são negativos, $79 \%$ o faziam; dos que tinham dúvida, $85 \%$ acendiam. O que impressiona, de fato, é o alto índice dessa prática entre os descrentes e duvidosos. Se se inverte o cruzamento, teremos que, entre os católicos que acendiam velas, $55.5 \%$ acreditavam em vida após a morte, $22.5 \%$ não acreditavam e $22 \%$ tinham dúvidas.

Essa "brincadeira" com os dados dos questionários encontra, assim, fundamento nos discursos e práticas dos meus informantes, estando implícito ou explícito no que foi descrito mais acima. O que temos aqui é um "jogo" de composição e recomposição de crenças-dúvidas-ceticismo em que é possível ter dúvidas se há vida após a morte e mesmo assim acender velas; é 
possível crer em vida após a morte, ter dúvidas se as rezas ajudam os mortos e ser cético quanto à eficácia das velas; é possível ainda ser cético quanto aos vivos se comunicarem com os mortos, mas crer que há um dia especial em que os mortos podem "reencontrar-se" com os vivos. Há aqui uma dialética entre a crença, a dúvida e o ceticismo que é própria do processo reflexivo religioso, sendo talvez o que explique a diversidade, complexidade e poder criativo dos sistemas religiosos. De qualquer forma, ou por causa disso mesmo, é bom ter em mente que a dúvida não é unívoca, pois ela se dá em níveis distintos: no mais intenso, esta põe em xeque todo o sistema cosmológico, podendo levar à conversão a outro sistema; em níveis intermediários, a dúvida põe em xeque elementos pontuais ou parciais, ou mesmo a eficácia de certos ritos dentro do sistema cosmológico, sem colocar em questão o próprio sistema. Assim, pode-se duvidar da eficácia da vela na ajuda aos mortos, ou mesmo da eficácia de todo o complexo de Finados, continuando a ser católico e a acender velas, como faz Ana.

A dinâmica da crença/dúvida/ceticismo em Finados, entretanto, só pode ser melhor compreendida a partir da inclusão da questão da "tradição" e da questão do "engajamento/comprometimento".

Voltemos, então, a discutir mais particularmente o ritual de acender vela. Como visto, $84.5 \%$ dos católicos pesquisados que foram ao cemitério em Finados afirmaram acender velas. Quando perguntados "por quê?" (questão aberta), muitos são aqueles que falam, a título de explicação, que é por tradição, apesar da motivação de oferecer luz aos mortos aparecer com mais força. Quero deixar aqui de lado a questão da luz, que implica uma clara segurança na eficácia da vela (apesar de não necessariamente), e me voltar ao significado da "tradição" nesse contexto. Melhor dizendo, pretendo refletir sobre a vela articulando-a à realização (ou performance) ${ }^{28}$ do ritual, aos que têm dúvida sobre a vida após a morte, ${ }^{29}$ à tradição e ao comprometimento.

Seria interessante retomar aqui as ideias de Severi (2002) e aprofundá-las um pouco mais. Assim, para este autor, a realização ritual religiosa é em si mesma reflexiva, fonte, portanto, tanto de dúvida quanto de crença e descrença. Complexificando isto, ele concebe que:

Reflexividade é, neste caso, situada dentro do contexto ritual. Podemos concluir, então, que o conceito de reflexividade, como aplicado para contextos rituais, se estende para além da mera existência de uma atitude de ceticismo para com a crença ritual. [...] Penso que poderíamos ir ainda mais além, e identificar casos em que a reflexividade (ou certo tipo de autorrepresentação) se põe como a premissa, e não como o resultado final da ação ritual (Severi 2002:27). 
Esta concepção da reflexividade como premissa do ritual e intrínseca à performance ritual, e não apenas como post-facto, é fundamental para entender a prática do ritual de acender velas em Finados, mesmo quando articulada à descrença ou à dúvida na vida após a morte, ou mais precisamente, como aquilo que dá condição a esta articulação. Assim, no contexto de Finados, o que se tem intrínseco ao ritual de acender velas é a reflexividade, ou o julgamento de sua eficácia naquilo a que o rito se propõe. ${ }^{30}$ Esta reflexividade, entretanto, só pode ser desenvolvida, por sua vez, na articulação e no contexto das representações católicas sobre a morte, os mortos e a relação destes com os vivos. Assim, prática e representação dialeticamente fundamentam a reflexividade religiosa, ao mesmo tempo em que são dinamisadas por esta última.

Contudo, se o que acabo de dizer parece convincente, isto não explica realmente porque $44,5 \%$ dos católicos que responderam o questionário e que afirmaram acender velas têm dúvidas ou não acreditam em vida após a morte, por exemplo, ${ }^{31}$ e por que quase $20 \%$ desses mesmos católicos que realizam o ritual da vela justificam o seu ato pela tradição. Creio que esse fenômeno fica mais inteligível se for introduzida a ideia de ritual commitment, ao mesmo tempo em que se procura compreender como a "tradição" é operacionalizada neste contexto.

O conceito de comprometimento ritual foi desenvolvido por Humphrey e Laidlaw e tem ganhado espaço entre os antropólogos, sobretudo aqueles que tendem a adotar uma abordagem cognitiva do fenômeno religioso (p. ex., Whitehouse 2002). Segundo os autores:

Atos ritualizados em tradições litúrgicas são socialmente prescritos e se apresentam para os atores individuais como "dado" e exteriores a eles. Porque os atos ritualizados são estipulados dessa forma, uma nova situação aparece: ao contrário de, como é normalmente o caso na vida cotidiana, o ato de uma pessoa ter seu sentido dado por suas intenções, com a ação ritual o ato em si mesmo aparece como já formado, quase como um objeto, algo do qual o ator deve "receber". Nessa situação transformada, as intenções e pensamentos do ator não fazem qualquer diferença para a identidade do ato performado. Você agiu, seja lá o que está sonhando naquele momento. Além disso, uma larga variedade de ações pode "contar como" um ato ritual. Esta situação não é nem um acidente nem uma questão de hábito inconsciente. Resulta de um ato positivo de concordância em uma ordem social estipulada (o comprometimento ritual). Com efeito, essas formas de ritualização removem a possibilidade de existir significado intrínseco nos atos rituais (Humphrey e Laidlaw apud Collins 2005:329). 
O argumento é o de que, tendo em vista a "exterioridade" dos rituais litúrgicos, a sua realização não implicaria uma intencionalidade pessoal, pois não haveria nos rituais um sentido intencional intrínseco a eles, em que "[...] os participantes estavam unidos na performance mesmo se suas noções do sentido do rito eram incompletas e contraditórias" (Humphrey e Laidlaw apud Severi 2002:27). ${ }^{32}$ Assim, como resume Severi:

Os atos realizados durante um rito regularmente aparecem para demandar um comprometimento do ator, mesmo quando o ator não os compreende. Por esta razão, estes atos tornam-se o roteiro sobre o qual um número de diferentes, até contraditórios significados, pode ser projetado (Severi 2002:27).

Haveria então a priori um engajamento/compromisso do fiel com a sua religião, traduzido na ação ritual, e que daria sentido à realização do rito, mesmo quando este, em si mesmo, parece vazio de sentido. O caso de Flora pode ser assim compreendido: católica que diz não acreditar em vida após a morte, pois "morreu, acabou", Flora se dirige todos os anos ao cemitério de Casa Amarela em Finados para rezar e acender velas: trata-se, para ela, de um compromisso com a sua mãe - que era irmã/devota das almas — seu compromisso é o de continuar cumprindo as obrigações e a tradição que a sua mãe deixou. Assim, ela reza e acende velas pelos mortos, ${ }^{33}$ pelo compromisso e pela tradição.

Contudo, se aqui o comprometimento de Flora parece ater-se à relação com sua mãe, pode-se inferir também que este compromisso pode ser instaurado a partir de uma tradição, ao mesmo tempo em que dá condições para a continuidade desta tradição. E é aqui que, creio, pode-se pensar na motivação da "tradição" para a realização do ritual de acender vela. Este entendimento me conduz às argumentações elaboradas por Gadamer em relação à concepção de tradição e prejuízos/preconceitos. Ele parte da ideia de que, depois do Iluminismo, a noção de "prejuízo/preconceito", ligada à noção de tradição e de autoridade, adquiriu uma conotação negativa, pois o prejuízo seria aqui percebido como prejudicial ao pensamento livre e racional, o qual não deveria ter barreiras para poder progredir. A argumentação do autor se ancora, então, sobre a construção de dois tipos de prejuízos: um positivo e um negativo. Nesse sentido:

"Prejuízo/preconceito" não significa julgamento errado; ao contrário, o conceito de prejuízo/preconceito implica que ele possa receber uma apreciação positiva ou negativa. É preciso retornar ao latim praejudicium para preservar na palavra um acento positivo ao lado do acento negativo (Gadamer 1976:109). 
Haveria então, segundo o autor, um prejuízo legítimo, que estaria fundado na autoridade de outras pessoas e do passado. O interesse na reflexão de Gadamer ${ }^{34}$ entretanto, apoia-se exatamente sobre a afirmação de que a autoridade

[...] não tem seu fundamento último em um ato de submissão e de abdicação, mas em um ato de aceitação e de reconhecimento: reconhecemos que o outro é superior em julgamento e em perspicácia, que o seu julgamento nos supera, que ele tem proeminência sobre o nosso. Igualmente, a autoridade não é propriamente concedida, mas adquirida e deve ser necessariamente adquirida por qualquer um que a almeja. Ela se baseia sobre o reconhecimento, portanto sobre um ato mesmo da razão que, consciente de seus limites, concede a outros uma maior perspicácia (1976:118).

É por esta razão que explicar uma atitude pelo argumento da autoridade e da tradição, ou seja, por meio de "prejuízos", não significa o abandono de toda reflexividade e liberdade das pessoas. Pois, como assegura Gadamer:

[...] na realidade a tradição não cessa de ser um fator de liberdade e da própria história. A tradição, mesmo a mais autêntica e a mais respeitável, não se realiza somente de modo natural, em virtude da força da preservação disto que se pensa existir; contudo, ela solicita ser afirmada e cuidada. Ela é essencialmente preservação. Como tal, a encontramos trabalhando em toda transformação histórica. Mas, a preservação é um ato de razão, um daqueles, é verdade, que passam despercebidos (1976:120).

E ele conclui que "[...] em todo caso, a preservação não é menos um ato de liberdade do que a agitação e a inovação" (1976:121). O raciocínio do filósofo ajuda, assim, a confirmar a minha intuição: a realização do ritual da vela, em particular, e de Finados em geral, motivada pela "tradição", é um ato de reflexividade. Isto porque os prejuízos positivos, constituídos pela autoridade (da Igreja, da comunidade ou da família) e pela tradição (escrita ou oral) para os indivíduos implicados têm um sentido que não abdica do julgamento e da interpretação, ou seja, da reflexividade. Assim, realiza-se e reafirma-se uma tradição ritual após submetê-la a um processo de avaliação, de reflexividade, que se completa através da realização do ritual, reflexividade esta alimentada pela dinâmica da dúvida, do ceticismo e da crença. 


\section{À guisa de conclusão}

Retornando ao início do artigo e fazendo eco à reflexão de Carneiro da Cunha, parece evidente que a escatologia católica é lócus de reflexividade e especulação. Mas é necessário complementar que não só o pensamento escatológico, como também toda a ritualidade que está implicada nesta escatologia é também fonte de reflexividade. O ritual de Finados é, portanto, paradigmático como espaço e tempo privilegiado para se perceber e compreender a dialética da dúvida-crença-ceticismo intrínseca à reflexividade religiosa, em que o compromisso não é de menor importância, assim como a tradição, e como essa dinâmica é, de fato, uma das possibilidades criativas e dinamizadoras da cosmologia católica.

Não se pode esquecer, todavia, que, para além e através da dinâmica reflexiva, o dia da Saudade é também (ou, portanto) um período para se afirmar um pertencimento a uma identidade religiosa, ao mesmo tempo em que se cumprem as obrigações e os engajamentos para com os entes queridos e o catolicismo: para os membros desta religião, "fazer" Finados é um sinal de catolicidade, engajamento, observância e pertencimento. Para a maioria desses católicos, Finados implica a vela e a reza, além do amor, da salvação e do "estar" em família.

O período de Finados é bom, assim, para pensar e para celebrar!

Recebido em 15 de janeiro de 2009

Aprovado em 10 de janeiro de 2010

Mísia Lins Reesink é professora do Departamento de Antropologia e Museologia e da Pós-Graduação em Antropologia/UFPE. E-mail: <emreesink@gmail. com>

\section{Notas}

* Uma primeira versão deste texto foi apresentada no GT Religião e Sociedade/ ANPOCS-2008. Agradeço aqui aos comentários e sugestões dos participantes deste GT. Agradeço, particularmente, a leitura cuidadosa e os comentários de E. Reesink. 
${ }^{1}$ Vale salientar que Carneiro da Cunha não afirma que quando há uma ortodoxia no campo da reprodução da sociedade não haja possibilidade de conflitos e contradições, ao contrário. Mas a autora deixa claro que a ortodoxia tem de fato um papel dominante.

${ }^{2} \mathrm{O}$ limbo é um espaço praticamente desaparecido entre os entrevistados. Vale lembrar que o Vaticano aboliu o limbo em 2007.

${ }^{3}$ Isso pode ficar mais interessante se levarmos em conta dados de questionário aplicado em cemitérios do Recife no período de Finados, em 1998. Diante da questão "para onde vai a alma depois da morte?" - questão aberta que permitia múltiplas possibilidades - foram referidos, além dos lugares ortodoxos (céu, inferno, purgatório e limbo - os quais classifiquei na categoria "clássica"), 40 tipos de opções "outras". Esta multiplicidade pôde ser classificada por mim em seis grandes categorias: "espírita/espiritualista" (16\%); "materialista" (9\%); "divina" (24\%); "cristã" $(19 \%) ;$ "merecimento" (26\%); "vagando" (6,5\%) - vale lembrar que um entrevistado pode ter citado mais de um tipo diferente de espaço/categoria. Pode-se acrescentar, ainda, que estas quatro últimas categorias têm um fundo comum católico-cristão, que diz respeito à relação entre Deus, julgamento, merecimento e espaço recebido. Na realidade, essa relação diversidade-fundo comum da escatologia católica pode ser melhor entendida a partir da adoção de uma perspectiva de interpretação concêntrica do campo católico (Reesink 2007). Para uma análise detalhada e aprofundada sobre a concentricidade católica e a sua "cosmografia", ver Reesink 2003.

${ }^{4}$ A pesquisa do primeiro período resultou na minha dissertação de mestrado (Lins [Reesink] 1995); a do segundo, na minha tese de doutorado (Reesink 2003).

${ }^{5}$ Foram aplicados 213 questionários em 1998, nos cemitérios de Casa Amarela e de Santo Amaro; a aplicação dos questionários fazia parte de minha pesquisa para o doutorado (que contou com bolsa da Capes) sobre rituais e representações de morte no bairro de Casa Amarela, em Recife. Além desses questionários aplicados nos cemitérios no período de Finados, outro semelhante foi aplicado nas duas áreas do bairro de Casa Amarela, onde pesquisei, com um total de 207 entrevistados. Aproveito para salientar que a aplicação desses questionários tinha (e tem) uma intenção prioritariamente heurística, funcionando como um instrumento de auxílio à pesquisa qualitativa desenvolvida. Não há, portanto, qualquer intenção estatística de generalização, sendo as possíveis inferências elaboradas referentes apenas ao próprio universo pesquisado.

${ }^{6}$ Como exemplo disto, há a discussão de Whitehouse (2002) sobre a transmissão religiosa através da reflexividade e repetição ritual: ele procura demonstrar, a partir de uma abordagem explicitamente cognitiva, que a reflexividade e a repetição ritual são intrínsecas ao processo de transmissão religiosa, mas que haveria níveis de reflexividade entre eles.

${ }^{7}$ O original em francês La fonction symbolique foi publicado em 1979. 
${ }^{8}$ Nesse sentido, tomo aqui a crença, a dúvida e o ceticismo em seus sentidos simples, ou seja: a crença como certeza positiva, o ceticismo como certeza negativa, a dúvida como inconclusão, indefinição ou recusa de tomada de posição.

${ }^{9}$ Apesar da relevância intrínseca da prova nesta articulação, não tratarei desta questão aqui, tendo em vista o escopo deste artigo.

${ }^{10}$ De uma maneira geral, a estrutura dos ritos de passagem se apresenta em três etapas ou momentos: separação, liminaridade (transição) e agregação (Van Gennep 1969 [1909]). Contudo, como já comentou Danforth (1982), no fenômeno da morte há muitas formas de separação, de agregação e, portanto, de margem. Assim, no contexto dos católicos de Casa Amarela, pude perceber algumas recomposições desta estrutura, segundo o ponto de vista de onde se posiciona. Nesse sentido, em relação ao processo da morte, há a separação do morrente do mundo dos vivos, sua condição transitória de moribundo (nem morto, nem vivo) e, finalmente, sua integração na condição de morto. Isto implica dizer que os ritos de oblação - cuidar do moribundo (Thomas 1985) - se transformariam aqui em ritos de transição. Para uma maior discussão sobre estas diferentes formas que os ritos de passagem assumem e para uma análise detalhada de todas as etapas do complexo ritual funerário católico, ver Reesink 2003 e 2006.

${ }^{11}$ Segundo J. Le Goff (1981), provavelmente entre 1024 e 1033. Seria ainda interessante notar que este autor concebe uma relação entre a instituição da Festa dos Mortos e a elaboração do purgatório na Idade Média. Vale ainda ressaltar que, segundo Fournié (1987), além de Finados, outras três festas de mortos foram instituídas ao longo da Idade Média, por exemplo, em 14 de janeiro. A Igreja, contudo, conservou apenas o 2 de novembro para festejar os seus mortos.

${ }^{12}$ Ao contrário do que pensa a maioria dos pesquisadores, não creio que esta época conserve atualmente qualquer fundo "pagão", o qual "coincide pouco com a concepção que a Igreja católica procura dar desde que ela introduziu essa festa no calendário litúrgico" (J. H. Déchaux 1997:135). Esta interpretação parece-me profundamente baseada em uma abordagem essencialista do campo católico, desconsiderando as dinâmicas construtivistas das lógicas culturais.

${ }^{13}$ Segundo os dados do questionário aplicado no bairro de Casa Amarela, em 1998, 61\% dos católicos preferiam ir ao cemitério no dia mesmo dos mortos, 4\% manifestaram preferência por Todos os Santos e 35\% se disseram indiferentes em relação ao primeiro ou ao segundo dia de novembro.

${ }^{14}$ A meu conhecimento, é o sociólogo J. H. Déchaux (1997) que realizou, em relação à França contemporânea, a melhor reflexão sobre este período. Além disso, trata-se de um trabalho importante no que tange ao catolicismo em geral, pois fornece pontos de comparação interessantes para pensar este período no mundo católico.

${ }^{15}$ Em Casa Amarela, além do período de Finados, outras datas são reservadas para se visitar os mortos: as segundas-feiras, dia das almas, e o dia que os irmãos ou devotos das almas costumam cumprir as suas obrigações; dia dos pais e dia das 
mães. É claro que nestes dois últimos casos os visitantes dos cemitérios são aqueles que perderam ao menos um de seus pais.

${ }^{16}$ A estrutura básica do ritual de Finados no Brasil é bastante semelhante à descrita por Déchaux (1997) para a Toussaint na França, que eu mesma pude constatar na observação que fiz nesta data (em 1999 e 2000), com exceção das velas que, na França, não estão presentes. Vale lembrar que aqui se trata da descrição "mínima" da estrutura do ritual de Finados. Para uma descrição detalhada, ver Reesink 2003.

${ }_{17}$ Dos católicos que responderam ao questionário em 2007, 60\% afirmaram acender vela em casa quando não vão ao cemitério no período de Finados. Para uma discussão sobre Finados em casa, ver Reesink 2003.

${ }^{18}$ Vale ressaltar que a ausência de túmulos não impede a visita aos cemitérios. Assim, muitos são os católicos que se dirigem, nestas condições, ao cemitério de Casa Amarela acender velas, cujo local privilegiado para a realização do ritual era ao pé de uma das paredes das salas de velórios deste cemitério.

${ }^{19}$ Deve-se lembrar ainda que Finados é o dia de culto de muitos santos, chamados de santos de cemitérios, e que atraem muitos devotos nesta data a esses locais. Ver, por exemplo, S. Oliveira 2008.

${ }^{20}$ Em relação à escatologia católica, como já esbocei mais acima, esta é, de uma maneira geral, bastante complexa. Entretanto, em se tratando do lugar intermediário, em particular, há uma complexidade maior, que ultrapassa a ideia do purgatório (Reesink 2003).

${ }^{21}$ Vale ressaltar outro aspecto: Seu Breno evoca a realização do ritual de Finados como um tipo de penitência, cujo caráter de obrigação parece não apagar certo lado prazeiroso, apresentado mais acima por Seu Lemos e reafirmado pela satisfação manifesta por Seu Breno. Nesse sentido, na elaboração do ritual de Finados, o prazer e o sofrimento parecem co-existir.

${ }^{22}$ Talvez fosse interessante notar que, diante da questão de múltipla escolha "em intenção de quem reza em Finados", os católicos parecem rezar mais fortemente pelas almas do purgatório (49.5\%), pelos pais (39.5\%) e pelas mães (37\%).

${ }^{23}$ A questão permitia duas respostas: sim e não. Em seguida, perguntava-se, de forma aberta, o porquê disso para os dois casos.

${ }^{24}$ Os trabalhos que analisaram estas relações nas culturas católicas não falam da vela (Cátedra 1987, para a Espanha; Déchaux 1997, para a França). Quando a vela é evocada parece que tem sempre um papel desigual (Charuty 1997, para a Europa ocidental, sobretudo, Portugal).

${ }^{25}$ A análise de B. Tito Figueirôa (1995) sobre a construção das relações metonímicas e metafóricas com a vela é bastante pertinente e interessante. Entretanto, 
parece-me que os exemplos que ele dá para chegar a estas conclusões não demonstram completamente estas duas relações. Creio que as relações que são descritas se referem todas à metáfora, pois a vela é aí pensada como símbolo, mesmo que de forma diferente. A distinção reside, penso, em uma que considera a vela como símboloemblema, enquanto a outra a vê como símbolo possuindo uma eficácia.

${ }^{26}$ Entretanto, o mais comum é o uso nativo de crer e saber como sinônimos. É bom lembrar aqui a discussão de Pouillon sobre o caráter ambivalente do verbo crer, que pode ter o sentido de saber.

${ }^{27}$ Esta questão só admitia três respostas: sim, não, tem dúvidas.

${ }^{28}$ Prefiro aqui guardar a forma portuguesa realização no lugar do termo inglês performance. Assim, entendo realização no sentido que Turner (1990 [1974]) dá à performance.

${ }^{29}$ Pode-se aqui considerar também os católicos que acendem velas e são céticos $(22.5 \%)$ ou têm dúvidas $(22 \%)$ em relação à vida após a morte.

${ }^{30}$ Creio que estes três momentos reflexivos podem ser ativados juntos ou autonomamente, dependendo do contexto religioso e das disposições individuais dos fiéis.

${ }^{31}$ Como já dito, há várias composições e correlações, dependendo da temática envolvida, no que se refere a esses números obtidos sobre a dúvida, ceticismo e crença. Por exemplo, entre os católicos que acendem velas, apenas $2.0 \%$ eram céticos e $12.5 \%$ tinham dúvidas se as rezas, de fato, ajudam os mortos.

${ }^{32}$ Não pretendo aqui discutir nem adotar todas as implicações e ponderações da teoria desses autores (ver para tanto Whitehouse 2002 e Collins 2005), e sim aproveitar o insight do ritual commitment na realização de Finados.

${ }^{33}$ Flora é a minha informante mais "íntima", que conheço desde 1993. O curioso é que, depois de vários anos sem contato - desde 1999, quando voltei a pesquisar em Casa Amarela - em Finados, em 2007, uma das primeiras pessoas que encontrei no cemitério foi ela.

${ }^{34}$ A elaboração teórica de H. Gadamer (1976) desenvolve-se prioritariamente sobre questões de método. O filósofo argumenta que, para uma aplicação verdadeira de uma ciência hermenêutica, é preciso considerar os prejuízos positivos e a tradição como fonte também de verdade e de construção histórica. Segundo ele, é apenas quando se leva em conta estes dois componentes da história que esta pode se tornar mais compreensível. Além disso, ele afirma que a própria démarche científica, assim como toda démarche humana, também se apoia sobre argumentos de autoridade e de tradição, portanto de prejuízos. 


\section{Referências bibliográficas}

CARNEIRO DA CUNHA, Manuela. 1986. Antropologia do Brasil: mito, história, etnicidade. São Paulo: Brasiliense/ Edusp.

CÁTEDRA, Maria. 1987. "Entre bêtes et saints: esprits des vivants et esprits des morts chez les vaqueiros de alzada". Études Rurales, 105-106:65-78.

CHARUTY, Giordana. 1997. Folie, mariage et mort: pratiques chrétiennes de la folie en Europe occidentale. Paris: Seuil.

COLLINS, Peter. 2005. "Thirteen ways of looking at a 'ritual'". Journal of Contemporary Religion, 20(3):323-342.

DANFORTH, Loring M. 1982. The death ritual of rural Greece. Princeton: Princeton University Press.

DÉCHAUX, Jean-Hugues. 1997. Le souvenir des morts: essai sur le lien de filiation. Paris: PUF.

EVANS-PRITCHARD, E. E. 1978. Bruxaria, oráculos e magia entre os Azande. Rio de Janeiro: Zahar.

FAVRET-SAADA, Jeanne. 1977. Les mots, la mort, les sorts. Paris: Gallimard.

FIGUEIRÔA, Bartolomeu. 1995. Entre almas, santos e entidades outras no Rio de Janeiro: mediadores e mediações na sociedade brasileira. Tese de doutorado em Antropologia, Rio de Janeiro, PPGAS/ MN/ UFRJ.

FOURNIÉ, Michelle. 1987. "Les prêtres du purgatoire: XIV et XV ${ }^{\mathrm{e}}$ siècles". Études Rurales, 105-106:93-121.

GADAMER, Hans-Georg. 1976. Vérité et méthode: les grandes lignes d'une herméneutique philosophique. Paris: Seuil.

HERTZ, Robert. 1905-1906. "Contribution à une étude sur la représentation collective de la mort". L'Année Sociologique, X:49-137.
HOJBJERG, Christian K. 2002. "Religious reflexivity: essays on attitudes to religious ideas and practice". Social Anthropology, 10(1):1-10.

LE GOFF, Jacques. 1981. La naissance du purgatoire. Paris: Gallimard.

LÉVI-STRAUSS, Claude. 1975. Antropologia estrutural. Rio de Janeiro: Tempo Brasileiro.

LINS (REESINK), Mísia. 1995. Morte, católicos e imaginário: o caso do Alto do Reservatório, Casa Amarela. Dissertação de Mestrado em Antropologia, Recife, UFPE.

POUILLON, Jean. 1982. "Remarks on the verb 'to believe'". In: M. Izard e P. Smith (orgs.), Between belief and transgression. Chicago: Chicago Press. pp. 1-8.

OLIVEIRA, Simone G. 2008. Três "Santas do Povo": um estudo antropológico sobre santificações populares em Minas Gerais. Tese de doutorado em Ciências da Religião, Juiz de Fora, UFJF.

REESINK, Edwin B. 1999. "A Salvação: as interpretações de Canudos à luz da participação indígena e da perspectiva conselheirista". Raízes, XVIII(20):147-158.

REESINK, Mísia Lins. 2000. "O regime de milagre em tempos de Nossa Senhora". Revista Anthropológicas, 11:124-138.

. 2003. Les passages obligatoires: cosmologie catholique et mort dans le quartier de Casa Amarea, à Recife (Pernambuco-Brésil). Thèse de Doctorat, École des Hautes Études en Sciences Sociales, Paris. . 2005. "Para uma antropologia do milagre: Nossa Senhora, seus devotos e o Regime de Milagre". Caderno CRH, 18:267-280. 
- 2006. Les passages obligatoires: cosmologie catholique et mort dans le quartier de Casa Amarea, à Recife (Pernambuco-Brésil). Lille: ANRT. . 2007. "Pour une perspective concentrique du catholicisme brésilien". Social Compass, 54(2):315-333.

. 2008. "Sobre fé e milagre: uma perspectiva cosmológica da fé e do milagre como 'categorias de entendimento' no catolicismo brasileiro". $26^{a}$. RBA, mimeo.

SEVERI, Carlo. 2002. "Memory, reflexivity and belief: reflexions on the ritual use of language". Social Anthropology, 10(1):23-40.

SCHMITT, Jean-Claude. 1994. Les revenants: les vivants et les morts dans la société médiévale. Paris: Gallimard.

THOMAS, Louis-Vincent. 1985. Rites de mort: pour la paix des vivants. Paris: Fayard.

TOREN, Christina. 2006. "Como sabemos que é verdade? O caso do mana em Fiji". Mana. Estudos de Antropologia Social, 12(2):449-477.

TURNER, Victor. 1990 [1974]. Dramas, fields, and metaphors: symbolic action in human society. Ithaca and London: Cornell University Press.

VAN GENNEP, Arnold. 1969 [1909]. Les rites de passage: études systématiques des rites. Paris: Mouton \& Co./Maison des Sciences de l'Homme.

Whitehouse, Harvey. 2002. "Religious reflexivity and transmissive frenquency". Social Anthropology, 10(1):91-103. 
Resumo

A análise dos processos de reflexividade religiosa vem ganhando espaço no campo da antropologia da religião, em que se busca examinar de que forma práticas e crenças se tornam objeto de reflexão de pessoas ou grupos religiosos. Nesse sentido, e a partir de dados etnográficos, este trabalho pretende refletir sobre o "dialógo" que se estabelece entre a dúvida, o ceticismo e a crença na realização do ritual católico de Finados, em particular, o ritual de acender velas, em cemitérios de Recife. Este artigo toma, assim, o período de Finados como lócus privilegiado para pensar a dinâmica reflexiva da dúvida-ceticismo-crença entre católicos recifenses, considerando ainda que o ritual e as suas implicações reflexivas não podem ser compreendidas sem levar em conta as representações que estes católicos elaboram sobre as relações entre os mortos, os vivos e o "outro mundo".

Palavras-chave Católicos, Finados, Crença, Dúvida, Velas

\section{Abstract}

Analysis of religious reflexivity has becomes increasingly present in the anthropology of religion, in particular investigations into how practices and beliefs the object of reflection of believers and religious groups. Here I turn to ethnographic data to explore the 'dialogue' between doubt, scepticism and belief in the performance of the Catholic ritual of All Souls' Day at cemeteries in Recife, especially the ritual lighting of candles. All Souls' Day provides an ideal context for discussing the reflexive dynamics of doubt-scepticism-belief of Catholics living in Recife. The ritual and its reflexive implications cannot be understood without taking into account the representations of these believers concerning the relations between the dead, the living and the 'other world.'

Key words Catholics, All Souls Day, Belief, Doubt, Candles. 